\title{
SOSIALISASI PENYUSUNAN LAPORAN KEUANGAN UMKM BERDASARKAN SAK EMKM PADA ANGGOTA KOMUNITAS KETRAMPILAN PEREMPUAN TLOGO KREASI DI KELURAHAN TLOGOSARI KULON KOTA SEMARANG
}

\author{
Ratna Wijayanti \\ Suratman \\ Eviatiwi Kusumaningtyas Sugiyanto* \\ Universitas Semarang; eviatiwisugiyanto@usm.ac.id
}

A R T I C L E I N F O

Article history:

Received 12 Juli 2020

Revised 30 Juli 2020

Accepted 25 Agustus 2020

Key words:

Tlogo Kreasi, Financial Report, $S M E$ 's, SAK EMKM

\section{A B S T R A C T}

The Tlogo Kreasi Women's Skill Community, Tlogosari Kulon Village, is an SMME that stands based on the hobbies of some housewives in making crafts, and then traditionally sold between friends and local residents, though the community is getting bigger, they do not have the knowledge about proper financial management. This background, the community service team will encouraged their understanding and knowledge about how to prepare financial reports based on SAK EMKM, so they will understand and be able to apply proper financial reporting. The approach used in this case is a participatory training approach, through outreach and workshops. The material for this financial report based on the needs of the community who do not really understand the importance of financial reports as a support to the progress of community development. The results of this service are increased participant understanding and skills in making financial reports based on SAK EMKM.

\section{A B S T R A K}

Komunitas Keterampilan Perempuan Tlogo Kreasi di Desa Tlogosari Kulon merupakan salah satu UKM yang berdiri atas dasar hobby beberapa ibu rumah tangga dalam membuat kerajinan, kemudian secara tradisional di jual antara teman dan warga sekitar. Meski komunitasnya semakin besar, tetapi mereka tidak memiliki pengetahuan tentang manajemen keuangan dalam menjalakan usaha. Dengan latar belakang tersebut, tim pengabdian masyarakat akan mendorong pemahaman dan pengetahuan mereka dalam hal keuangan yaitu tentang bagaimana menyusun laporan keuangan berdasarkan SAK EMKM, sehingga mereka memahami dan mampu menerapkan pelaporan keuangan yang tepat. 
Pendekatan yang digunakan dalam hal kegiatan adalah pendekatan pelatihan partisipatif, melalui penyuluhan dan pelatihan. Materi laporan keuangan ini didasarkan pada kebutuhan masyarakat yang kurang begitu memahami pentingnya laporan keuangan sebagai penunjang kemajuan pembangunan masyarakat. Hasil dari pengabdian ini adalah peningkatan pemahaman dan keterampilan peserta dalam membuat laporan keuangan berdasarkan SAK EMKM.

\section{PENDAHULUAN}

Komunitas Keterampilan Perempuan Kota Semarang Tlogo Kreasi merupakan komunitas yang dibentuk berdasarkan kesamaan hobi dari ibu-ibu rumah tangga yaitu menyulam. Personil komunitas ini yaitu Widyarini, Rosmiati dan Robbi. Ketiganya merupakan ibu rumah tangga yang meluangkan waktu bersama menyalurkan hobi mereka. Pada akhirnya komunitas ini mengangkat salah satu dari ibu rumah tangga tersebut sebagai pimpinan komunitas. Bakat dan kreativitas yang terus dilakukan di waktu luang menghasilkan beberapa karya yang memiliki nilai jual. Beberapa keterampilan yang dihasilkan ibu-ibu rumah tangga tersebut antara lain sulam pita, kreasi limbah dan kreasi kain percaya. Produk yang dihasilkan kemudian dijual kepada tetangga sekitar dan daerah sekitar tempat tinggal komunitas tersebut dengan harapan dapat meningkatkan pendapatan sehari-hari. Adapun modal untuk biaya operasional kegiatan diperoleh dari iuran anggotanya.

Potensi yang dimiliki oleh komunitas ini adalah keahlian dalam menghasilkan produk-produk ekonomi kreatif seperti kreasi sulam pita dalam bentuk tas, kerudung, dan mukena. Selain sulam, kreasi yang dihasilkan juga berasal dari limbah seperti dompet dan tas dari limbah bungkus makanan atau tali rafia, atau kain perca sisa konveksi. Peluang yang dapat ditangkap dari keahlian komunitas tersebut adalah produk yang dihasilkan diminati oleh pasar yang terlihat dengan adanya pesanan dari masyarakat sekitar terkait produk tersebut, dan setiap kali produksi biasanya selalu terjual. Hal ini mendukung ciri wirausaha yang cocok bergerak aktif dalam suatu komunitas yang dijadikan sumber gerak bagi anggota komunitas lainnya. Seorang wirausaha ialah seseorang yang inovatif, kreatif dan mampu mewujudkannya kreatifitasnya agar meningkatnya kesejahteraan diri di lingkungan dan masyarakat.

Alasan penyaluran hobi menjadi salah satu alasan usaha yang dijalankan oleh komunitas ini belum memiliki pengelolaan yang memadai, seperti pemasaran produk hanya dipasarkan ala kadarnya, mitra cenderung menunggu pesanan dan hanya menawarkan produk di lingkungan sekitar. Selain itu dari sisi keuangan, mitra belum memperhitungkan harga jual yang sesuai dengan produk. Mindset yang dimiliki komunitas adalah anggapan bahwa yang penting uang dapat diputar untuk membeli bahan baku lagi, bahkan pembeli sering kali hanya mengganti biaya produksi saja untuk memiliki produk yang dihasilkan. Hal tersebut menyebabkan keuntungan dan kerugian tidak dapat terdeteksi. Kelemahan dari sisi keuangan lainnya adalah komunitas tidak memiliki pembukuan keuangan ataupun bukti-bukti transaksi keuangan. 


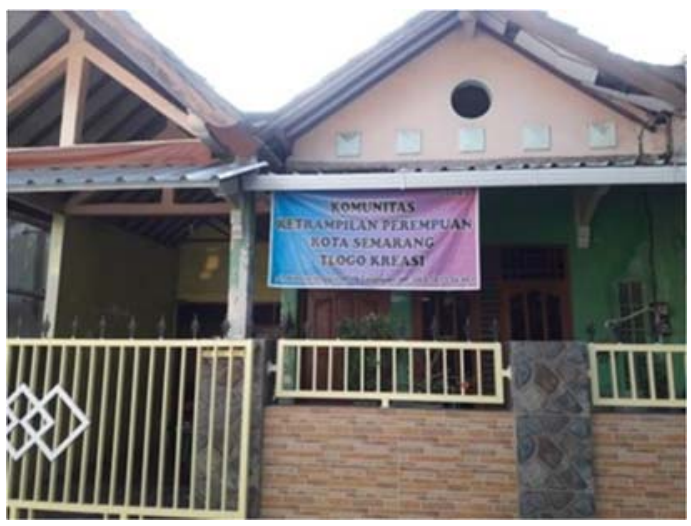

Gambar 1. Rumah Ibu Widyarini sebagai Pusat Berkumpulnya Komunitas

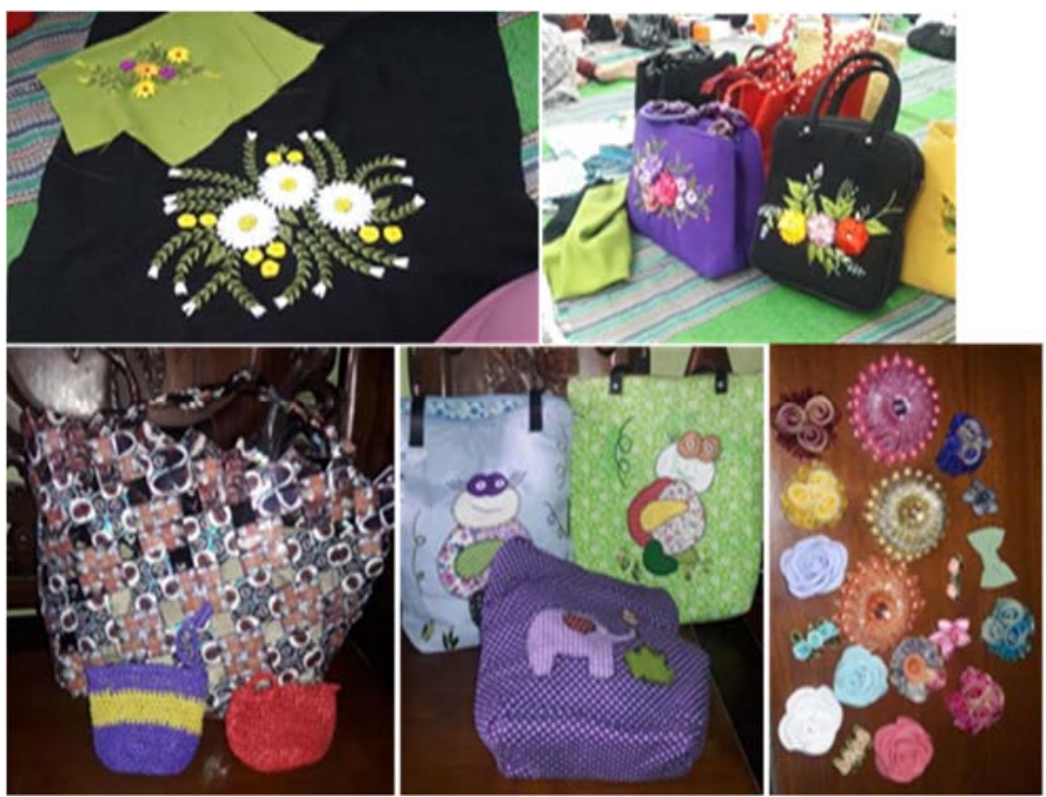

Gambar 2. Produk-Produk Tlogo Kreasi

Berdasarkan latar belakang tersebut, tim pengabdian terdorong untuk mensosialisasikan pemahaman serta pengetahuan tentang cara pembuatan laporan keuangan berdasarkan SAK EMKM kepada anggota komunitas Ketrampilan Perempuan Tlogo Kreasi agar dengan tujuan para anggota komunitas dapat memahami dan mampu menerapkan pembuatan laporan keuangan yang benar dan tepat. Permasalahan ini sejalan dengan yang disampaikan oleh Sholikin dan Setiawan (2018) yang menjelaskan bahwa mayoritas UMKM masih belum siap mengimplementasikan SAK EMKM. Dalam penyampaian materi, sebelumnya para peserta diberikan pengetahuan tentang SAK EMKM yang merupakan kepanjangan dari Standar Akuntansi Keuangan Entitas Mikro Kecil Menengah Makro. SAK EMKM dirancang secara khusus sebagai patokan standar akuntasi keuangan pada UMKM (Badria \& Diana, 2018). Standar Keuangan ini disusun dan disahkan oleh IAI atau Ikatan 
Akuntan Indonesia sebagai sebuah organisasi profesi yang menaungi seluruh akuntan di Indonesia melui laman websitenya. SAK EMKM ini merupakan salah satu dorongan kepada pengusaha-pengusaha di Indonesia agar dapat berkontribusi secara signifikan dalam pengembangan UMKM yang lebih maju (Kusuma \& Lutfiany, 2018). Indonesia memiliki 4 (empat) tipe SAK yang berlaku, yaitu: SAK (Standar Akuntansi Keuangan), SAK-ETAP (Standar Akuntansi Keuangan untuk Entitas Tanpa Akuntansi Publik), PSAK-Syariah (Pernyataan Standar Akuntansi Keuangan Syariah) dan SAP (Standar Akuntansi Pemerintah).

IAI selanjutnya menyusun SAK yang lebih sederhana dari SAK-ETAP yaitu SAK EMTM pada pertengahan 2015. Hal ini dikarenakan masih banyaknya UMKM di Indonesia yang belum mampu untuk membuat serta menyusun laporan keuangan yang sesuai dengan SAK yang berlaku. Ada 6 langkah dalam proses pembuatan laporan menurut Baridwan (2008) yaitu pertama, mengumpulkan dan mencatat transaksi pada jurnal. Transaksi merupakan kegiatan umum yang sering dilakukan oleh perusahaan, baik transaksi pembelian, penjualan, penukaran barang, sewa ataupun transaksi lainnya. Bukti transaksi merupakan hal yang sangat penting, hal yang sangat utama dalam akuntansi sehingga bukti transaksi tidak boleh hilang. Bukti transaksi merupakan dasar pencatatan dalam membuat laporan keuangan. Bukti transaksi ini dapat berupa nota, kuitansi, faktur ataupun jenis bukti lainnya. Langkah pertama dalam membuat laporan keuangan adalah mencatat transaksi yang dilakukan oleh perusahaan di tahun berjalan pada jurnal. Semua transaksi yang berkaitan dengan aktivitas operasional perusahaan harus dicatat dalam jurnal dengan rinci. Kedua, memposting jurnal ke dalam buku besar, setelah membuat jurnal, langkah kedua yaitu mem-posting jurnal ke dalam buku besar. Buku besar merupakan rincian dari setiap akun-akun yang ada. Tidak sulit untuk melakukan hal ini, hanya memindahkan transaksi yang sudah di catat dalam jurnal ke akun-akun yang sesuai dengan rinci.

Ketiga, menyusun neraca saldo, yaitu neraca saldo adalah suatu daftar rekening-rekening buku besar dengan saldo debit atau kredit. Langkah selanjutnya setelah membuat buku besar yaitu menyusun neraca saldo. Daftar rekening pada buku besar dikelompokkan ke dalam kelompok pasiva atau kelompok aktiva. Neraca saldo digunakan untuk mengecek keseimbangan debet dan kredit dari seluruh rekening. Langkah keempat, mengumpulkan data yang diperlukan untuk membuat jurnal penyesuaian, yaitu beberapa transaksi mungkin ada yang belum tercatat atau transaksi terjadi di akhir saat tahap pembuatan laporan keuangan dan masih ada yang tidak sesuai dengan keadaan di akhir periode, sehingga data tersebut dikumpulkan untuk membuat jurnal penyesuaian. Langkah ke lima, menyusun neraca lajur yatu untuk memudahkan penyusunan laporan keuangan maka kita perlu menyusun neraca lajur atau kertas kerja yang dimulai dari data di neraca saldo dan disesuaikan dengan data yang diperoleh dari jurnal penyesuaian. Selanjutnya, saldo yang sudah disesuaikan akan terlihat pada kolom neraca saldo yang telah disesuaikan dan merupakan saldosaldo yang akan dilaporkan dalam neraca dan laporan rugi laba. Langkah keenam, membuat laporan keuangan, yaitu laporan yang sudah disusun di neraca lajur tinggal di tulis dengan rapi sesuai ketentuan atau standar laporan keuangan. Hal ini karena dalam neraca lajur sudah dipisahkan jumlah-jumlah yang dilaporkan dalam neraca atau laporan rugi laba. Informasi yang disajikan dalam laporan keuangan sangat penting, karena mencerminkan kinerja perusahaan dan dapat digunakan untuk pengambilan 
keputusan.

Pengelolaan keuangan perusahaan bisa dilakukan dengan mudah menggunakan bantuan software akuntansi online. Sesuai dengan namanya, SAK EMKM dirancang khusus untuk Usaha Mikro, Kecil, dan Menengah sesuai Undang Undang No 20 Tahun 2008 yang berlaku aktif mulai 1 Januari 2018. Kerangka pelaporan keuangan SAK EMKM ini diharapkan dapat membantu entitas dalam melakukan transisi dari pelaporan keuangan berdasarkan kas ke pelaporan keuangan dengan dasar akrual. Informasi yang dihasilkan dalam laporan keuangan berguna sebagai pengambilan keputusan yaitu pertimbangan mengenai pembelian bahan baku dan alat-alat yang digunakan, keputusan mengenai harga, mengajukan permohonan pembiayaan kepada bank, penambahan aset usaha, dan lain sebagainya.

Penyuluhan dan pelatihan SAK EMKM sangat dibutuhkan oleh UMKM, karena selain laporan keuangan merupakan hal yang penting dalam sebuah usaha, SAK EMKM dirancang khusus untuk Usaha Mikro, Kecil, dan Menengah sesuai Undang Undang No 20 Tahun 2008 yang berlaku aktif mulai 1 Januari 2018 (Janrosl, 2018). Tujuannya adalah sebagai acuan dalam pembuatan laporan keuangan yang berisi informasi posisi dan kinerja keuangan. Informasi tersebut berguna bagi kreditor maupun investor untuk pengambilan keputusan ekonomi sekaligus pertanggungjawaban manajemen kepada pemilik usaha (Ningtyas, 2017). Berdasarkan hasil analisis situasi di atas, maka permasalahan mitra dapat diidentifikasi sebagai berikut: (1) keterbatasan pengetahuan para pelaku usaha di kelurahan Tlogosari Kulon mengenai laporan keuangan berdasarkan SAK EMKM yang terbaru; (2) belum menguasai cara pembuatan laporan keuangan yang benar dan tepat menurut SAK EMKM karena usaha dikerjakan dengan proses manajemen yang sederhana.

\section{METODE PELAKSANAAN}

Tahapan kegiatan dalam pelaksanaan pengabdian kepada masyarakat dapat terlihat dalam Gambar 1. 


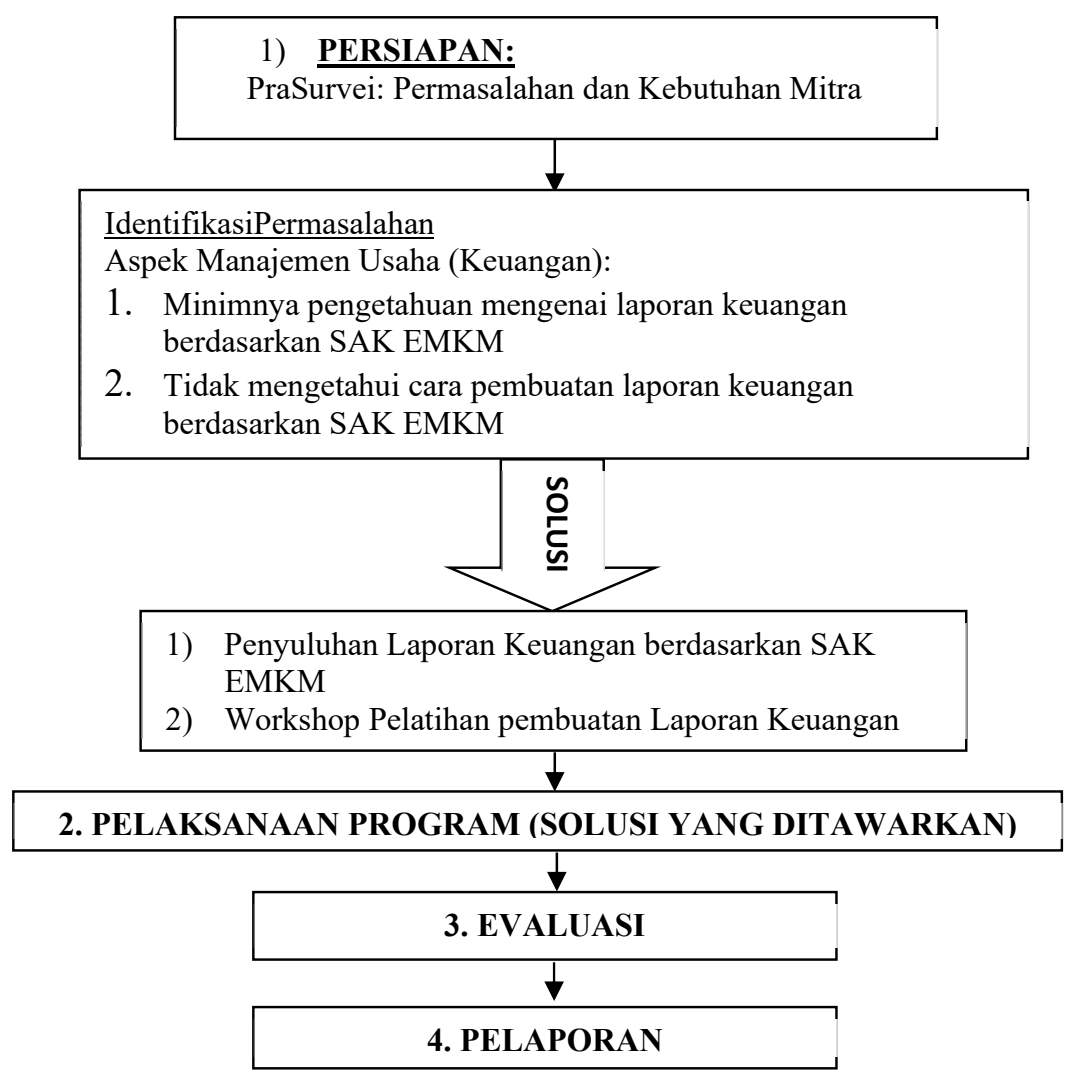

Gambar 1. Tahapan Kegiatan

Adapun prosedur kerja yang dilaksanakan oleh pengabdian adalah:

\section{Persiapan}

Tahap persiapan merupakan tahap awal sebelum pelaksanaan kegiatan. Dalam tahap ini ada beberapa hal yang dilakukan, yaitu:

a. Pra Survei: Identifikasi Permasalahan dan Kebutuhan Mitra

b. Pembentukan Tim: Pembentukan Tim untuk memberikan solusi bagi permasalahan dan kendala yang dihadapi oleh mitra. Tim terdiri dari berbagai kompetensi yang dipadukan untuk memberikan solusi pemecahan masalah mitra

c. Pembuatan Proposal: pembuatan proposal yang menawarkan solusi untuk permasalahan dan kebutuhan mitra

d. Koordinasi antara Tim dengan Mitra: Untuk merencanakan pelaksanaan secara konseptual, operasional, serta job description masing-masing Tim dan Mitra

\section{Pelaksanaan}

Bekerjasama dengan pihak kelurahan dan anggota komunitas Ketrampilan 
Perempuan Tlogo Kreasi di Tlogosari Kulon Kecamatan Pedurungan Kota Semarang. Semua pelaksanaan kegiatan dilakukan di kantor komunitas di Kelurahan Tlogosari Kulon. Pelaksanaan pengabdian terdiri dari dua kegiatan utama yaitu penyuluhan laporan keuangan dan workshop pelatihan pembuatan laporan keuangan berdasarkan SAK EMKM.

\section{Metode Pendekatan}

Metode pendekatan yang digunakan dalam mencapai tujuan adalah pendekatan participatory training, yaitu pendekatan yang menekankan pada partisipasi penuh dari mitra dan pendampingan dalam mencapai tujuan. Pendekatan participatory training dilakukan melalui beberapa langkah pembelajaran dalam bentuk penyuluhan dan workshop (pelatihan).

\section{Evaluasi}

Evaluasi program dilaksanakan dengan membandingkan keadaan mitra sebelum dan sesudah program dilaksanakan. Keberhasilan program ditujukan dengan adanya perubahan yang positif dari keadaan mitra yaitu peningkatan kemampuan, pengetahuan dan ketrampilan dalam membuat laporan keuangan berdasarkan SAK EMKM.

\section{HASIL DAN PEMBAHASAN}

Kegiatan pengabdian kepada masyarakat ini merupakan perwujudan salah satu Tri Dharma Perguruan Tinggi yang dilaksanakan oleh civitas akademika Program S1 Manajemen. Dalam kegiatan ini civitas dituntut untuk memberikan kontribusi terhadap masyarakat dengan menyalurkan keilmuan yang dimiliki guna mendukung pengembangan kehidupan masyarakat khususnya kelompok-kelompok ekonomi produktif. Kegiatan pengabdian kepada masyarakat telah dilakukan dan berjalan lancar meski dihadiri sedikit anggota komunitas dikarenakan kondisi pandemi Covid19 yang menganjurkan diminimalkannya pertemuan dan kerumunan dalam jumlah yang besar. Pada kegiatan penyuluhan dan pelatihan yang dilakukan oleh kami sebagai tim pengabdian total yang hadir sejumlah 11 orang yang terdiri 5 dosen dan 6 anggota komunitas. Kegiatan pengabdian ini dilakukan selama 6 jam ini berisi penyuluhan tentang Laporan Keuangan berdasarkan SAK EMKM serta pelatihan pembuatan laporan keuangan yang diadakan pada hari Kamis, 23 April 2020 yang diadakan mulai dari pukul 08.00 sampai dengan pukul 14.00 WIB di rumah Ibu Widyarini selaku Ketua Komunitas Ketrampilan Perempuan Tlogo Kreasi.

Kegiatan penyuluhan dibagi tiga sesi yaitu penyuluhan yang berkaitan laporan keuangan yang sesuai dengan SAK EMKM, pelatihan pembuatan laporan keuangan, dan sesi terakhir adalah tanya jawab berkaitan dengan laporan keuangan SAK EMKM. Pada sesi penyuluhan diberikan oleh Ibu Ratna Wijayanti, SE, MM, sedang sesi pelatihan dijelaskan oleh Bapak Suratman,SE., MM.,CA.,Akt dan Ibu Eviatiwi KS., SE., MM. Saat sesi ketiga yaitu tanya jawab diberikan penjelasan secara bergantian antara tim pengabdian. Dua kegiatan inti dalam pengabdian ini adalah pemberian penyuluhan dan pelatihan yang berkaitan dengan materi sosialisasi laporan keuangan 
berdasarkan SAK EMKM dengan cara menyediakan materi kepada para anggota komunitas yang hadir kemudian menjelaskannya secara langsung teorinya dan juga praktek pembuatan laporan keuangan sesuai SAK EMKM. Kegiatan berikutnya adalah sesi evaluasi dari tim pengabdian kepada anggota komunitas yang hadir untuk mengetahui sejauh mana manfaat yang diperoleh setelah mengikuti penyuluhan dan pelatihan pembuatan laporan keuangan yang sudah diberikan. Penilaian evaluasi ini dilakukan melalui tanya jawab antara anggota komunitas dengan tim pengabdian yang ada di Tabel 1 .

Tabel 1. Daftar Pertanyaan para Peserta

\begin{tabular}{|c|c|c|}
\hline No. & Pertanyaan Peserta & Jawaban \\
\hline 1 & $\begin{array}{l}\text { Apakah sebenarnya tujuan dan arti } \\
\text { penting laporan keuangan bagi komunitas } \\
\text { /UMKM? }\end{array}$ & $\begin{array}{l}\text { Laporan keuangan ini bagi UMKM memiliki } \\
\text { tujuan memberikan informasi mengenai } \\
\text { kondisi usaha yang tengah berjalan sesuai } \\
\text { jangka waktu tertentu.Sedangkan arti } \\
\text { pentingnya adalah untuk mengetahui untung } \\
\text { atau rugi usaha yang sedang dilakukan, jika } \\
\text { pengeluaran lebih besar dibanding } \\
\text { pendapatan maka usaha dikategorikan rugi } \\
\text { tetapi apabila kondisi sebaliknya maka usaha } \\
\text { mendapatkan keuntungan sesuai yang } \\
\text { diharapkan. }\end{array}$ \\
\hline 2 & $\begin{array}{l}\text { Jangka waktu pembuatan Laporan } \\
\text { keuangan paling pendek bagi UMKM } \\
\text { sebaiknya berapa lama? }\end{array}$ & $\begin{array}{l}\text { Jangka waktu paling singkat untuk } \\
\text { mengevaluasi kondisi usaha sebaiknya } \\
\text { dilakukan setiap triwulan atau tiga bulanan } \\
\text { sekali. }\end{array}$ \\
\hline 3 & $\begin{array}{l}\text { Apa saja yang termasuk aktiva lancar bagi } \\
\text { UMKM? }\end{array}$ & $\begin{array}{l}\text { Yang termasuk aktiva lancar bagi UMKM } \\
\text { yaitu kas, piutang usaha, persediaan bahan } \\
\text { baku/alat. }\end{array}$ \\
\hline 4 & $\begin{array}{l}\text { Posisi atau keadaan yang bagaimanakan } \\
\text { yang sebaiknya muncul di laporan } \\
\text { keuangan? }\end{array}$ & $\begin{array}{l}\text { Posisi yang sebaiknya muncul di laporan } \\
\text { keuangan adalah tergambarkan dari laporan } \\
\text { laba rugi yang sebaiknya menunjukkan hasil } \\
\text { untung, Laporan Perubahan Modal yang } \\
\text { sebaiknya menunjukkan jumlah modal yang } \\
\text { dikeluarkan jumlah pastinya berapa dan } \\
\text { dialokasikan menjadi apa saja dan Laporan } \\
\text { Neraca sebaiknya menunjukkan jumlah harta } \\
\text { kekayaan, modal dan hutang yang dimiliki. }\end{array}$ \\
\hline 5 & $\begin{array}{l}\text { Laporan manakah yang menggambarkan } \\
\text { hasil bersih usaha dari UMKM? }\end{array}$ & $\begin{array}{l}\text { Laporan yang menggambarkan hasil bersih } \\
\text { usaha UMKM adalah laporan keuangan laba } \\
\text { rugi }\end{array}$ \\
\hline 6 & $\begin{array}{l}\text { Laporan keuangan terdiri dari berbagai } \\
\text { macam bentuk laporan seperti Neraca, } \\
\text { Laporan Laba Rugi, Laporan Perubahan } \\
\text { Modal. Manakah laporan yang paling } \\
\text { utama bagi UMKM? }\end{array}$ & $\begin{array}{l}\text { Semua laporan seperti neraca, laporan laba } \\
\text { rugi, laporan perubahan modal dan laporan } \\
\text { arus kas semuanya sangat penting bagi } \\
\text { UMKM karena semua merupakan pencatatan } \\
\text { detil yang menggambarkan keseluruhan } \\
\text { transaksi yang terjadi yang dapat mendukung } \\
\text { pengambilan keputusan yang diperlukan bagi } \\
\text { pengelola UMKM yang berkaitan dengan }\end{array}$ \\
\hline
\end{tabular}


operasional usaha.

$7 \quad$ Apakah kalau banyak pengeluaran yang tidak tercatat dapat menunjukkan hasil laporan keuangan yang akurat?

8 Bagaimana caranya mennsosialisasikan materi laporan keuangan ini kepada anggota komunitas yang lain?

9 Bagaimana meyakinkan bahwa laporan keuangan yang dilakukan sudah benar adanya?

10 Apakah hasil penjualan yang terjadi tapi uang belum diterima juga dicatat dalam laporan keuangan?
Tidak, semakin banyak data yang memang terjadi tetapi belum tercatat akan membuat hasil laporan keuangan semakin tidak akurat.

Melakukan pertemuan pembelajaran dan melakukan latihan praktek pembuatan laporan keuangan secara bersama.

Apabila semua sudah dilakukan secara kaidah dan aturan yang ada maka bisa dipastikan langkah pembuatan laporan sudah benar.

Ya, dicatat sebagai piutang usaha
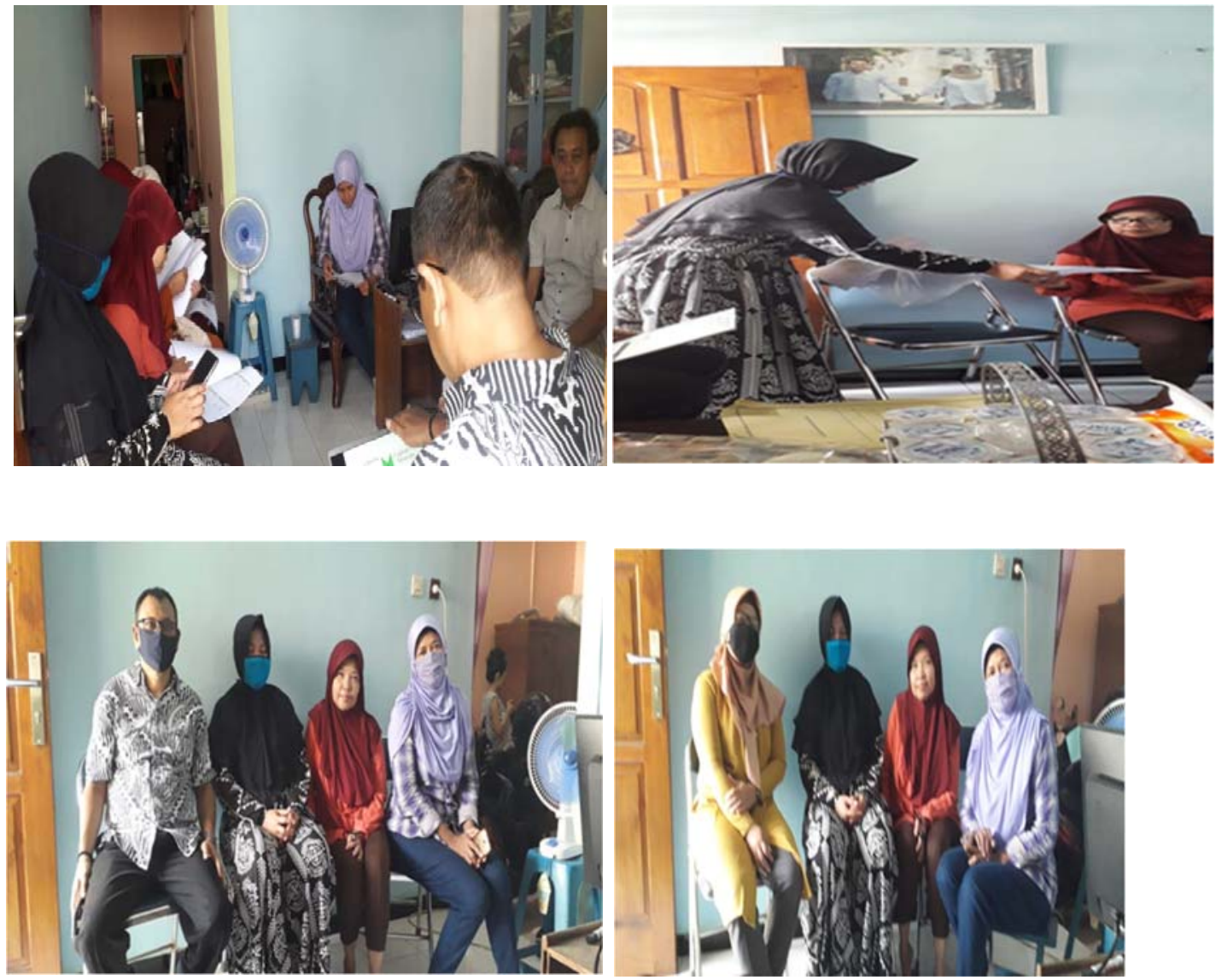

Gambar 2. Pelaksanaan Program Pengabdian

Pertanyaan yang diberikan oleh anggota komunitas menunjukkan keingintahuan mereka tentang bagaimanakah pembuatan laporan keuangan yang baik dan benar sesuai dengan SAK EMKM, serta respon baik dan kepuasan mereka setelah 
mendapatkan jawaban dari tim pengabdian berdasarkan pertanyaan yang diajukan. Dilaksanakannya praktik secara langsung pembuatan laporan keuangan juga menunjukkan bahwa mereka telah mempraktikkan ilmu yang sudah dijelaskan oleh tim pengabdian berkaitan dengan pembuatan laporan keuangan, meskipun masih menggunakan contoh transaksi dasar seperti pembelian bahan baku, alat dan honor tenaga kerja dari anggota komunitas yang membuat kerajinan. Ada dua laporan keuangan yang diajarkan kepadan komunitas yaitu laporan posisi keuangan dan laporan laba rugi. Anggota komunitas masih mengalami beberapa kendala dalam mempraktekkan pembukuan, misalnya dalam hal mengelompokkan jenis-jenis transaksi dan akun-akunnya, serta belum terbiasanya untuk tertib keuangan. Dalam pengamatan di lapangan anggota komunitas harus lebih disiplin melakukan pencatatan atas transaksi-transaksi keuangan yang terjadi pada usahanya.

Pengelolaan keuangan yang baik dan transparan memerlukan pengetahuan dan keterampilan. Berdasarkan pengamatan di lapangan ada beberapa faktor yang mempengaruhi sulitnya penerapan pembukuan atau pembuatan laporan keuangan oleh anggota komunitas diantaranya faktor internal yaitu ketidakpahaman para anggota tentang cara penyusunan laporan keuangan, ketidaktahuan anggota akan manfaat melaksanakan pencatatan keuangan, ketidakdisiplinan anggota dalam melaksanakan pencatatan keuangan, kekurangan SDM dalam melakukan pencatatan keuangan, serta ketidaksiapan sarana dan prasaranan seperti komputer untuk mendukung pembuatan laporan keuangan. Dari faktor eksternal kendala sulit diterapkannya praktek pemubukuan yaitu tidak adanya pengawasan yang menuntut komunitas ini harus membuat laporan keuangan, kurangnya fasilitator atau pendampingan yang membantu anggota komunitas dalam membuat laporan keuangan. Melalui kegiatan pengabdian kepada masyarakat ini, para anggota komunitas mengerti mekanisme pencatatan akuntansi, manfaat dan kebutuhan terkait pembuatan laporan keuangan untuk perkembangan usaha mereka.

\section{SIMPULAN}

Sebelum pelaksanaan kegiatan pengabdian kepada masyarakat, Komunitas Perempuan Tlogo Kreasi tidak memiliki laporan keuangan, namun hanya menggunakan nota-nota sebagai bukti penerimaan dan pengeluaran tanpa adanya pencatatan, sehingga keuntungan dan kerugian usaha tidak dapat terdeteksi dengan mudah. Setelah diadakannya kegiatan pengabdian kepada masyarakat yaitu penyuluhan dan pelatihan terkait pembuatan laporan keuangan SAK EMKM dapat disimpulkan bahwa anggota Komunitas Tlogo Kreasi telah mampu memahami materi mengenai laporan keuangan sesuai SAK EMKM dan mampu menyusun secara sederhana laporan keuangan sesuai SAK EMKM. Hal ini diketahui oleh tim pengabdian melalui kegiatan evaluasi yang dilakukan, baik berupa sesi tanya jawab, diskusi, dan praktik dalam membuat laporan keuangan meski masih sederhana.Hhasil evaluasi juga menunjukkan terdapat peningkatan pengetahuan dari para anggota komunitas terkait laporan laporan keuangan dan terdapat peningkatan keterampilan pembuatan laporan keuangan meski secara sederhana. Dalam praktiknya para anggota komunitas kesulitan dalam mempraktikkan dan menyusun laporan keuangan. Hal ini membutuhkan kedisiplinan dan ketekunan dari anggota komunitas untuk terus 
mempraktikkan ilmu-ilmu yang telah diajarkan. Hasil pengabdian ini diharapkan dapat memotivasi komunitas Ketrampilan Perempuan Tlogo Kreasi untuk terus menerapkan pencatatan laporan keuangannya sesuai dengan SAK EMKM yang telah disosialisasikan dan diajarkan sehingga mereka akan terus mengetahui secara riil aset aktif yang mereka miliki untuk selanjutnya dapat dikelola dan digunakan secara optimal. Berdasarkan simpulan tersebut, saran yang dapat diberikan yaitu masih diperlukannya pendampingan secara lebih intensif dan berkelanjutan kepada anggota komunitas, sebagai dukungan secara langsung apabila ditemukan kendala saat komunitas menerapkan pembuatan Laporan Keuangan sesuai SAK EMKM. Untuk itu kedepannya, Tim Pengabdian akan melakukan pendampingan terhadap anggota komunitas dalam rangka menciptakan budaya tertib pembukuan. Selain itu para anggota komunitas membutuhkan pedoman tertulis mengenai tahapan-tahapan penyusunan laporan keuangan dan juga panduan dalam pengelompokan akun atau pospos dalam laporan keuangan.

\section{DAFTAR PUSTAKA}

Badria, N., \& Diana, N. (2018). Persepsi pelaku UMKM dan sosialisasi SAK EMKM terhadap diberlakukannya laporan keuangan yang berbasis SAK EMKM 1 Januari 2018 (Studi kasus pelaku UMKM se-Malang). Jurnal Ilmiah Riset Akuntansi, 7(1), 55-66.

Baridwan, Z. (2008). Intermediate Accounting (8th ed.). Yogyakarta: BPFE Yogyakarta.

Janrosl, V. S. E. (2018). Analisis persepsi pelaku UMKM dan sosialisasi SAK EMKM terhadap diberlakukannya laporan keuangan yang berbasis SAK EMKM. Jurnal Politeknik Caltex Riau, 11(1), 97-105.

Kusuma, I. C., \& Lutfiany, V. (2018). Persepsi UMKM dalam memahami SAK EMKM. Jurnal Akunida, 4(2), 1-14.

Ningtyas, J. D. A. (2017). Penyusunan laporan keuangan UMKM berdasarkan standar akuntansi keuangan entitas mikro, kecil dan menengah (SAK-EMKM) (Studi kasus di UMKM Bintang Malam Pekalongan). Riset \& Jurnal Akuntansi, 2(1), $11-17$.

Sholikin, A., \& Setiawan, A. (2018). Kesiapan UMKM terhadap implementasi SAK EMKM (Studi UMKM di Kabupaten Blora). JIFA (Journal of Islamic Finance and Accounting), 1(2), 35-50. https://doi.org/https://dx.doi.org/10.22515/jifa.v1i2.1441 